\title{
CULTURAL DIVERSITY IN A CATHOLIC UNIVERSITY
}

\author{
MAERTEN H. PRins \\ JACQUES A. P. J. JANSSEN \\ MARINUS H. F. VAN UDEN \\ COR P. M. van HALEN \\ University of Nijmegen, The Netherlands
}

\begin{abstract}
The modern university is no longer a unified entity. Not only are there different faculties, but these faculties are clustered into a number of cultures, centered around variables that are unrelated to the content of the academic fields of study. This has an impact on the identity of a university, especially when this identity is based on religious affiliation. Our research shows that the Catholic University of Nijmegen does not have one identity for the university as a whole. We found a multitude of sub-identities or sub-cultures. Six faculty cultures were identified. One of those is the culture of the theology faculty, whose students were found to differ so significantly from those in other faculties that the faculty was considered a separate culture. If we can still speak of a Catholic identity, it is to be found there.
\end{abstract}

\section{INTRODUCTION}

The very name "Catholic university" combines two elements that both refer to a concept of unity. The church of the first centuries understood catholicity to mean wholeness and totality. The word catholic comes from the Greek word katholikos (or kata holon), meaning according to the whole. The term referred to the inward unity of the church.

The word university is derived from the Latin word universitas, meaning universe or whole. Since its origin in the 12th century, the university presented itself as a whole. Although universities had several faculties (beginning with the four faculties of theology, arts, law and medicine in the 13th century; Verger, 1978), they formed a civitas academica: an academic community with strong solidarity between teachers and students. The aim of university study was to shape a young man into a homo universalis. The German diplomat and scientist Wilhelm von Humboldt (1767-1835) had a profound influence in Europe with his vision of an ideal university. In his view, the aim of the university was to realize a unity of research and apprenticeship, schooling and upbringing, for the purpose of imparting an all-round humanist education [1]. Attending lectures was not the essential part of a university education: the important thing was to live for 
oneself and for science for a few years in a small community with likeminded peers, knowing one was in the company of well-educated adults dedicating themselves to the furthering and dissemination of science [2] (Von Humboldt, 1959). This is an ideal that has long been widely endorsed.

There was little variation within this academic world: students as well as staff were upper-class, conservative-liberal males. This shared background was reflected in shared opinions and world views, and led to criteria for selection that helped keep variance small. By no means was this academic world a reflection of the outside world, nor was the student population a reflection of the young generation. The traditional student, as Pinner (1963) described him, was stratum-oriented. Study was only a temporary interruption of his belonging to a particular stratum. Students were student through ascription: their qualities or attributes were independent of any specific expected performance (Parsons, 1951).

In the second half of the twentieth century, things began to change. Snow was probably one of the first to see a division emerging in the academic world. He saw two groups: the literary intellectuals and the scientists, and between them "a gulf of mutual incomprehension - sometimes hostility and dislike, but most of all lack of understanding" (Snow, 1956, p. 4). He used the term 'two cultures', meaning that the two groups did not share common attitudes, common standards and patterns of behavior, common approaches or assumptions. Much to his surprise, the publication of his conclusions set off a controversy in the academic world. Although many found his thesis an eye-opener, others wanted to uphold the ideal of a civitas academica, and insisted that even if an academic division existed, surely the notion of 'two cultures' was too strong, and this division was just a result of differences between fields of study.

Perhaps the best-known method of classifying the special characteristics of scientific communities is the Biglan classification. Biglan (1973) distinguishes three dimensions that characterize academic faculties: the hard/soft dimension (concern with a single paradigm), the pure/applied dimension (concern with application), and the life/non-life dimension (concern with life systems). These three dimensions characterize scientific communities on the basis of the subject matter of their discipline. However, focusing strictly on the subject matter was found to be inadequate when trying to capture the diversity of disciplinary and interdisciplinary fields (Stoecker, 1993). In an attempt to expand on Biglan's concepts, Becher (1989) adds the social dimensions convergent/divergent and rural/urban. Although this was not part of his research, he argues that academic groups (i.e. professors and staff) have their own traditions and taboos, territories 
and boundaries, fields of competition and pecking orders, tacit knowledge and hidden assumptions, and specific patterns of communication, publication, division of labor, hierarchies and careers. Somewhat mockingly, he calls these groups 'tribes'.

Thus the groups centered around the various university disciplines have traits that cannot be explained only by their epistemological characteristics. The concept of culture, however, is sufficiently broad and complex to cover all the relevant traits that differentiate the various discipline groups, from aspects of everyday life to the cognitive and social structures (Huber, 1990). Thus it appears that Snow's choice of the notion of 'cultures' was justified. As he explained in his second look, he chose the word carefully, and used the concept to denote a group of people linked by common habits, common assumptions and a common 'way of life' (Snow, 1964, p. 64).

The notion that discipline communities differ in the cultural practices and preferences that characterize the private lives of their members is supported by research. In the United States, Gaff and Wilson (1971) have discerned four separate cultures which they call faculty cultures: the cultures of the humanities, the social sciences, the natural sciences and the professional sciences. They see fundamental differences between professors of these four faculty cultures, differences "that extend beyond subject matters into the realm of values and ideology". Clear distinctions were found between the four faculty cultures in terms of educational values, teaching orientation, and life-style. With regard to the latter, professors of the four cultures differed in the types of the activities they enjoyed, their political views and their religious orientation. Similarly: in a study of the professorial staff at universities in Paris in the 1960s, Bourdieu (1988) came across divisions between the faculties of science, arts, law and medicine that could not be explained simply by differences in subject matter. He argues that the academic field ('le champ scientifique') consists of disciplines that can only be understood in their relations to each other, and that these relations transcend academic issues but also reflect the social structure in terms of economic, cultural and social power.

So we see that the academic world can no longer be considered a unified whole, but is made up of separate faculty cultures that center around factors not related to the subject matter of the particular academic disciplines, but rather based on shared life-style, values and ideology.

The very notion of a Catholic university, however, suggests a more or less explicit Catholic identity that would be expected to have a culturally unifying effect. A Catholic university possesses typical identity features that bind the staff as well as the students, and that possess a high level of 
continuity over time (De Wolff, 2000). The identity of the university is created through the interaction of university culture and university organization. This identity can be described as the total of values, norms and expectations that give direction to the activities of the staff of the university (Hermans, 1994).

It is conceivable that the explicit Catholic identity of a university would be capable of counterbalancing the fragmenting tendency that we find in the academic world today. At a Catholic university one might very well expect to still find a shared identity for the university as a whole. In our research, we set out to examine whether a single shared identity or culture can be found in the Catholic University of Nijmegen in the Netherlands. If no single, shared university culture exists, we wanted to see whether there is a sub-structure in which this Catholic identity can be detected.

\section{THE PROBLEM}

In the past century important changes have taken place at Dutch universities. The Dutch government made huge efforts to increase accessibility of university education and developed a system of study grants that is open to everybody and that is (still) among the best in Europe (Koppen, 1991, p. 45). As a result, university enrollment grew rapidly [3]. The increase in the number of students attending university coincided with three waves of emancipation. First, with the removal of financial barriers, young people from the middle and lower classes had the opportunity to attend university [4]. Second, there was a large increase in the number of religious young people, particularly Roman Catholics, to enter university [5]. And third, the number of girls entering university increased enormously with the emancipation of women [6].

The growing number of students from different backgrounds has led to an increase in variance within the student population. Students are no longer student by ascription, they are now students by achievement, or vocation-oriented (Pinner, 1963). The right of birth has been replaced by the right of accomplishment, and the emphasis has shifted from qualities or attributes to performance (Parsons, 1951).

The increase in the variance among students was more pronounced in Nijmegen than at other universities, because the three waves of emancipation were felt particularly strongly at the Catholic University of Nijmegen. The university was founded in 1923 as part of an explicit attempt to emancipate the Roman Catholic part of the population. The need for such emancipa- 
tion was first formulated in 1900 by Poelhekke (1990), who pointed out that only about $2 \%$ of Dutch professors and $6 \%$ of students were Catholics, even though Roman Catholics made up $40 \%$ of the Dutch population at large. The publication of Poelhekke's analysis brought about a renewal of cultural awareness among Roman Catholics, leading to an increase in the number of Catholic students and the founding of a Catholic university in Nijmegen (Matthijssen, 1958). The choice of Nijmegen as the location of a Catholic university was a natural one, since most Catholics live in the southern part of the Netherlands.

In other respects, too, the University of Nijmegen differs from the other Dutch universities. The number of students from lower- and middle-class families is higher in Nijmegen than anywhere else in the Netherlands (Koppen, 1991), and the proportion of female students is higher than the national average (57\% and 46\%, respectively, in 1995/1996).

The present study focuses on cultural differences between groups of students in the various academic disciplines. We chose to focus on students from a Catholic university because of the Catholic universities' dual focus on unity. If unity can still be found in the academic world, it must be sought at a Catholic university. We therefore set out to discover whether there is one shared identity or culture at the Catholic University of Nijmegen. If our research found that there is no such overarching university culture, we hoped to identify and describe the different faculty cultures and to find a sub-structure in which a Catholic identity still exists.

\section{Method}

In 1992, slightly over 1,100 questionnaires were sent to students of all disciplines at the Catholic University of Nijmegen in the Netherlands. 506 questionnaires $(45 \%)$ were returned, giving a representative view of the student population of Nijmegen. The average age of the sample population was 22.3 years.

In order to identify and describe the culture or cultures, a wide range of variables were included in the questionnaire. As Hochbaum rightly points out, "it is important for the researcher to be aware of the whole system. With the whole system in mind he is less likely to reify the component he is investigating (...), or to reduce the system to one level" (Hochbaum, 1976). Therefore we gathered information about students that related to three categories of world views: philosophy of life (including religious opinions), politics, and science (items related to scientific opin- 
ions and attitudes, but unrelated to choice or preference of a field of study). To reduce the great amount of information, several scales were constructed on the basis of factor analysis (principal components analysis with varimax rotation) (see appendix $\mathrm{A}$ ).

Four political scales were constructed: a political left-right scale (V6: reliability Cronbach's alpha $=.76$ ), a scale measuring political interest (V26: reliability Cronbach's alpha $=.85$ ), a scale for parliamentary political activity (V22: reliability Cronbach's alpha $=.87$ ), and a scale for extra-parliamentary political activity (V8: reliability Cronbach's alpha = .88). Also included in the analysis is the political party voted for (V7).

With regard to philosophy of life, the following scales were constructed: involvement in social affairs (V14: reliability Cronbach's alpha $=.84$ ), career orientation (V27: reliability Cronbach's alpha $=.78$ ), family-mindedness (V24: reliability Cronbach's alpha $=.76$ ), and personal development (V17: reliability Cronbach's alpha $=.74)$. Also included were questions about how often respondents read news magazines (V15), whether they attended general lectures organized by the university, known as Studium Generale (V3), whether they considered religion an important factor in their view on life (V10), how often they read or watched TV programs about religion (V18), and how often they attended church (V25).

The science-related items measured academic attitudes and opinions. While these items were science-oriented, they were not faculty-oriented per se. Six scales were constructed: job orientation (V4: reliability Cronbach's alpha $=.88)$, cognitive interest (theoretical orientation) (V23: reliability Cronbach's alpha $=.82)$, democratisation of the university (V12: reliability Cronbach's alpha $=.84)$, political relevance of study (V16: reliability Cronbach's alpha $=.84)$, belief in the importance of science for society (V28: reliability Cronbach's alpha $=.77$ ), and the social aspect of university study (V29: reliability Cronbach's alpha $=.79$ ). Questions were also asked to determine whether the respondents saw science as important for shaping their view of life (V20), the amount of time they spent on their studies (V1), how often they talked with others about their studies (V11), whether they thought about their studies outside the university (V5), how they viewed their chances of finding employment in their field (V2), whether or not they would accept a job not related to their field of study (V19), the time they estimated they would need to complete their program (V9), and whether they belonged to a fraternity/sorority (V13). The respondent's gender was also included in the analysis (V21). All of these variables were treated as independent variables.

The scores on the scales ranged from 1 to 5 , but the results were con- 
verted to dichotomous variables, using the mean score of the total group of respondents. The discipline to which the students belonged was treated as the dependent variable. Only those disciplines with five or more respondents were included, which brought the number of disciplines to 24 .

The technique used to combine this volume of information was a correspondence analysis. Correspondence analysis is a technique especially suited to nominal data, and is based on the frequencies in cross tabulations. One of the objectives of correspondence analysis is to graphically reflect the relationship between rows and columns in a table. The technique uses the Chi-square distances to plot a two-dimensional graph. The plot that we obtain by a correspondence analysis visualizes relations between variables and shows us which variables cluster.

Two elements are important for the interpretation of the plot. The first is the distance between a variable and the center. The greater the distance, the more outstanding this variable is. Variables that are close to the center are less outstanding and less relevant. The second important element is the angle between (imaginary) lines from the center to variables. The smaller the angle, the greater the correlation between the two variables. Two variables that lie on the same line are highly correlated. An angle of 90 degrees means zero correlation, while an angle of 180 degrees means a negative correlation (Lammers et al., 1989).

\section{REsults}

Since a faculty culture is made up of a field of characteristics not intrinsically linked with the subject matter of the academic discipline being studied, it should be possible to reproduce the academic field by looking at lifestyle variables. In a correspondence analysis, variables that are not directly related to the field of study are set off against the disciplines chosen by students. The variables that are used fall within three domains: philosophy of life (including religious opinions), political orientation and science orientation (items related to scientific opinions and attitudes, but unrelated to a field of study). The outcome of the analysis is a two-dimensional plot, in which the two dimensions account for 45 percent of the variance (the first dimension explains $27.6 \%$, the second dimension $17.5 \%$ ). This may seem like a small percentage, but when we consider that it takes 23 dimensions to account for 100 percent of the variance, the fact that the first two dimensions explain almost half of the variance is not bad. In the plot we can see that clustering indeed occurs. 


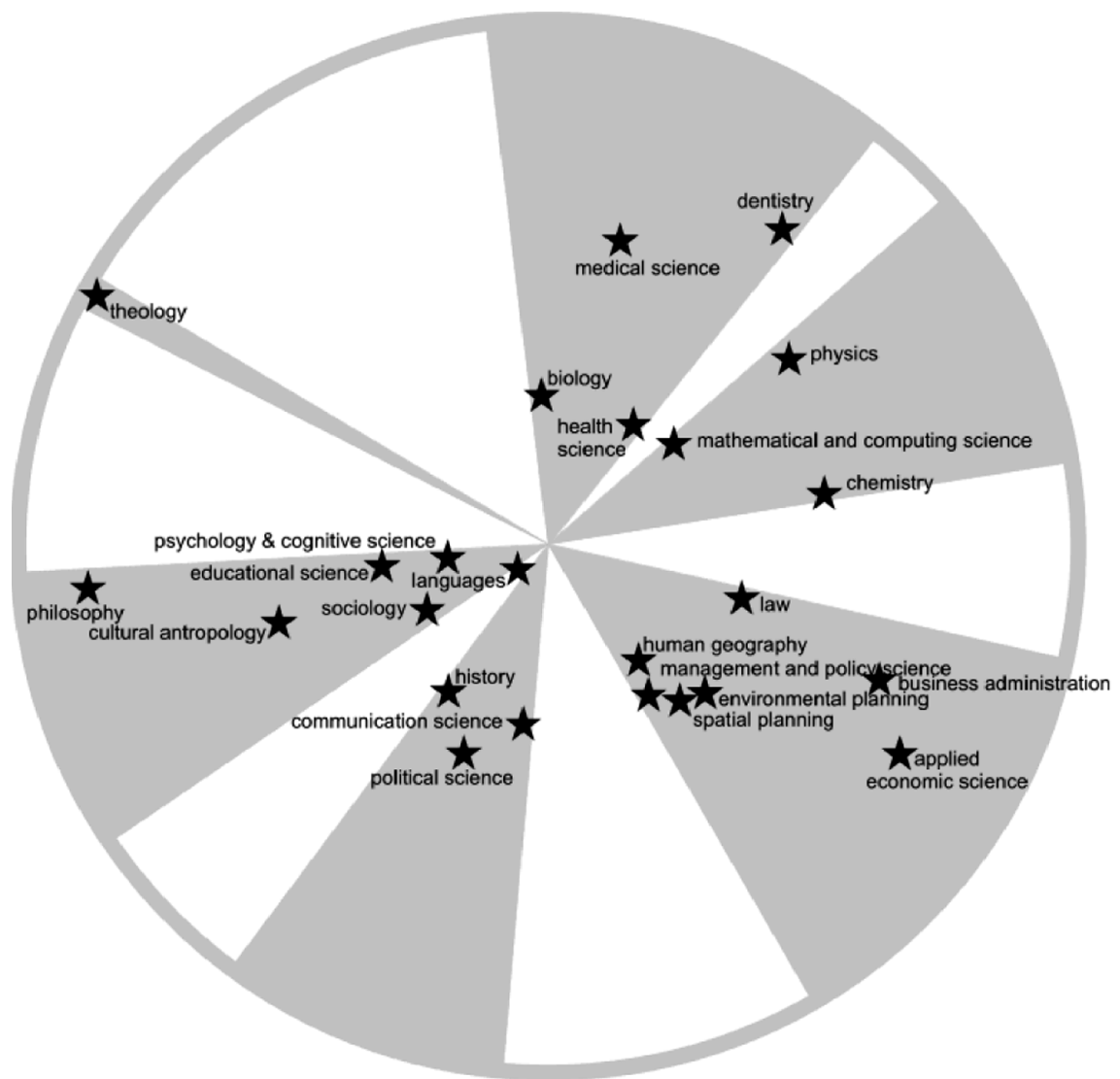

Plot 1. Correspondence analysis of academic disciplines and variables not directly related to the field of study.

In this plot, only the dependent variables, the academic disciplines, are depicted. The independent variables are of course included in the analysis, but are not depicted because they would make the plot indecipherable, given that there are 29 independent variables that contain a total of 62 categories ( 28 variables are dichotomous, and one variable - political party preference - contains six categories). These independent variables are listed in appendix A, sorted by domain, and numbered in an order that reflects the strength of their contribution to the plot.

The disciplines are scattered in all directions, but six clusters can be distinguished. To make interpretation easier, gray areas were added to the plot to indicate these clusters. We will describe these six clusters, or 
faculty cultures, one at a time and identify the variables that are typical of them.

\subsection{The 'medical' faculty culture}

The first cluster is the medical faculty culture. It comprises the disciplines of dentistry, medical science, health sciences, and biology.

The majority of the students in this cluster are female (72\% versus $62 \%$ in total sample), and the percentage is highest in health sciences $(93 \%)$. They are family-minded: they want to get married, start a family and grow old with the person they love. Most of them (74\%) do not read news magazines. Politically they are not very outspoken; they are not politically interested, and not politically active. Most of them vote for D'66, the Liberal Democratic party [7]. They spend a lot of time studying, 41 hours a week on average (the average in the total sample is 31 hours a week), and they expect that they will need a long time to complete their program of studies. Their studies play an important role in their lives, and they talk about them with others. Almost none of them are members of a sorority/fraternity, but $60 \%$ are members of a student association. They want to work in their discipline, and they perceive their chances of doing so as reasonably good.

\subsection{The 'natural sciences' faculty culture}

This faculty culture comprises the disciplines of physics, chemistry, and mathematics and computing science. Students in this cluster are similar to those in the medical cluster, the most striking difference being that while $72 \%$ of the medical students are female, only $21 \%$ of the natural science students are female. The natural sciences are typically male fields of study.

Even more so than the students in the medical cluster, students in this cluster are hard workers; they spend 45 hours a week on their studies and they expect to need a long time to complete their program. $60 \%$ are members of a student association. Their academic studies do not play an important role in their lives, and they do not talk about them much with others. They do not feel that their studies should be politically or philosophically relevant ('give insight into political or ethical matters'), nor do they value the social aspect of studying ('making friends, having regular contacts with fellow students'). The important thing in their view is to acquire theoretical knowledge. After university, they are sure that they will find work in their fields.

They are not very socially involved, nor are they interested in personal 
growth ('developing one's own philosophy of life, getting to know oneself better, listening and being empathetic to others'). $77 \%$ say they never read news magazines. Religion does not play a large role in their lives; three-quarters do not consider themselves to be members of any religious denomination, they do not attend church, they do no watch or listen to programs about religious topics, and more than half say they never talk about religious subjects. More so than students in the other faculty cultures they stand on the right wing of the political spectrum ("society is fair; people have equal opportunities, although some people are leaders and others followers; family, morality and decency need to be protected'). However, they are not politically active: one quarter say they don't know what party to vote for, the others vote for the Liberal Democrats (D'66) or Christian parties. They feel that science should have a greater impact on society and politics: politicians should listen more to scientists and should invest more in science, because science, in their view, is what keeps the world going around.

\subsection{The 'professional' faculty culture}

This culture comprises the disciplines of applied economic science, business administration, environmental science, spatial planning, law, management and policy science, and human geography. This cluster contains two faculties: law, and policy sciences with the exception of political science.

The students in this cluster are about equally divided between male and female. They are not involved in social affairs ("not interested in environmental issues, reforming society, fighting poverty') or personal growth ('developing one's own philosophy of life, getting to know oneself better, listening and being empathetic to others'). What they are interested in is achieving, getting ahead in society, getting a job that pays well. Religion does not play an important part in their lives; they do not watch programs or read articles on religious topics.

Students in these fields are right-wing. They are very interested in political issues, and vote for political parties on the right of the spectrum: Liberal Democratic (D'66), Christian or conservative. Half of them are politically active in parliamentary politics ('supporting a political candidate, being a member of a political party, going to political meetings'), but only a few are active in an extra-parliamentary politics.

They are not keenly interested in their program of study; and it has no impact on their lives. They spend relatively little time studying (26 hours a week), and they feel they can finish their program in a relatively short 
time (5 years). They do not feel that students should have a greater say in university matters, they do not feel the need for their studies to be political relevant, they are not interested in acquiring theoretical knowledge, nor do they feel that science should play a greater role in politics or society. They do not think about their studies in their spare time, although $18 \%$ are members of a fraternity/sorority (as compared with $12 \%$ in the total sample). They see the aim of their academic studies to be achieving a good job, a good career and a good social position, and students in this cluster are certain that they will find employment in their field of study.

\subsection{The 'social sciences' faculty culture}

This culture comprises the disciplines of political science, communication science, and history. Students in this cluster are the least family-minded: getting married and starting a family are not priorities. They are more interested in personal development: developing their own philosophy of life, getting to know themselves better, listening and being empathetic to others and so on. The majority say they read news magazines (63\%). Religion does not play an important part in their lives; they do not feel an affinity with any religious denomination, and they don't attend church.

Politically they are moderately left-wing: they vote for the Liberal Democratic (D'66) or Socialist parties. They are politically interested and active, both in a parliamentary ('supporting a political candidate, being a member of a political party, going to political meetings') and an extraparliamentary manner ('taking part in a political demonstration or march, supporting strikes, making or distributing political pamphlets').

Their academic studies do not play an important role in their lives, and they do not talk about them often when off campus. They do not spend much time studying (26 hours a week, with only 8 hours of classes), but they value the social aspect of student life. They perceive their chances of finding work in their field of study as small, but they do not mind taking a job outside their field.

\subsection{The 'humanities' faculty culture}

This culture comprises the disciplines of philosophy, cultural anthropology, educational science, sociology, psychology and cognitive science, and languages. In the plot the field of language and linguistics is located near the center, which means that students in this field are not very outspoken; they form the common denominator, so to speak. This field contains several small and diverging sections which - in further statistical analyses - 
were found to be situated near the center, but in all directions. The discipline of languages and linguistics is by no means a coherent culture. However, since it seems to be more closely related to the humanities than to any other group of faculties, it will be considered as one of them.

Students in this cluster are interested in personal development ('developing one's own philosophy of life, getting to know oneself better, listening and being empathetic to others'). Politically they are on the left; they vote for the Liberal Democrats or one of the small left-wing parties (26\% versus $20 \%$ overall). They are not very much interested in politics, but they are active mostly in extra-parliamentary politics ('taking part in a political demonstration or march, supporting strikes, making or distributing political pamphlets').

They see their academic studies more as a means of acquiring theoretical knowledge than as the stepping stone to a successful career. They talk about their studies in their spare time. They believe students should have a say in matters concerning their academic studies. Only a quarter are members of a student association. They are doubtful of their chances of finding a job in their field of study, although they would very much like to work in their field .

\subsection{The 'theology' faculty culture}

This culture is made up of only the discipline of theology. Logically speaking, this discipline could be considered a part of the 'humanities' group, but theology students were found to differ to such a degree from those in other faculties that they had to be classified as a separate faculty culture. Theology students also differ from all the other students, as illustrated in plot 1: the greater the distance between a variable (the discipline of theology) and the center, the more outstanding this variable is. This means that if languages students are considered prototypical students, then theology students are the most uncharacteristic students of the Catholic University of Nijmegen. Considering the Catholic identity of the university, this is certainly peculiar, since the majority of theology students identify themselves as Catholic (66 percent as compared to 25 percent overall). It is the only faculty culture in which the members have clear religious beliefs: religion plays an important role in their lives, they read $(100 \%)$ and watch (83\%) programs about religious issues, they talk about religious matters regularly (83\%) and they attend church $(33 \%$ attend more than three times a month).

There is considerable interaction between the students' field of study 
and their private lives, more than in any other faculty culture. In their free time, theology students think and talk a great deal about their academic studies. They do not see their studies as a road to a career, but as a means of acquiring theoretical knowledge. They think students should have a say in matters concerning their academic studies, and they feel that their studies should be politically or philosophically relevant. Only a small percentage are members of a fraternity/sorority, but they do attend Studium Generale lectures. They would like to work in their field, and most believe that they will find employment in that field.

Politically they are on the left; they vote for the smaller left-wing parties (58\% as compared with $20 \%$ in the total sample). They are moderately interested in politics, and although not active in a parliamentary manner, they are active in extra-parliamentary politics ('taking part in a political demonstration or march, supporting strikes, making or distributing political pamphlets'). Most (58\%) read news magazines, are involved in social affairs ('interested in environmental issues, reforming society, opposing poverty'), and believe that personal development is important ('developing one's own philosophy of life, getting to know oneself better, listening and being empathetic to others'). At the same time they are family-minded: they hope to get married, start a family and grow old with the person they love.

\section{CONCLUSION AND DISCUSSION}

Our research has shown that there is not one shared identity or culture in the Catholic University of Nijmegen. At the student level, clusters of disciplines are clearly discernible when we look just at extra-academic variables such as lifestyle and political preferences. These clusters of disciplines constitute six groupings which we have identified as the 'medical', 'natural sciences', 'professional', 'social sciences', 'humanities', and 'theology' faculty cultures. Each group is characterized by a unique mix of cultural practices and preferences, values, ideology, life-style and political and religious orientation.

Almost the same structure of faculty cultures was found earlier by Gaff and Wilson (1971). They identified four faculty cultures: the professional sciences, the social sciences, the humanities, and the natural sciences. According to our results, however, the latter two have to be split into what we call the 'humanities' and 'theology' cultures and the 'medical' and 
'natural sciences' cultures respectively. The underlying structure remains the same. Also, the same structure of (six) faculty cultures was found at the Catholic University of Leuven in Belgium (Prins, Janssen \& Hutsebaut, 1997). These are strong indications that a cultural fragmentation of the academic world is stable and exists over time. It should not be trivialized as Clark, for instance, has done, claiming that "sociologists who concentrate on characteristics imported into the academic profession by individual members from their personal background and prior experiences have been essentially looking at the least important components of academic culture" (Clark, 1987, p. 107).

The structure of faculty cultures identified here is remarkably parallel to the faculty structure of the university. In fact, we have been able to reproduce the classic universitarian faculty structure by using cultural variables that are not related to the fields of study per se. The medical faculty culture coincides with the faculty of medical sciences, plus the discipline of biology: all corporal disciplines. The natural sciences faculty culture comprises the faculty of natural sciences minus biology, and the faculties of mathematics and computing sciences: all theoretical subjects. The professional faculty culture corresponds with the faculties of law and of policy sciences (minus political sciences, which is more abstract). The social sciences faculty culture is something of an oddity: it combines three disciplines from three different faculties: political science, communication and history. This culture can be characterized as disciplines that deal with people in a somewhat abstract way, as opposed to the faculty culture of the humanities, which is made up of disciplines that deal with people in a more direct way. The humanities faculty culture consists of the faculties of social sciences (minus communication science), languages/arts (minus history), and philosophy. Finally, we have the faculty culture of theology, in a faculty that is concerned chiefly with supernatural, religious issues.

It is clear that there is no overarching culture at the catholic university of Nijmegen. The university is fragmented and six faculty cultures can be identified. University nowadays looks like an archipelago, a group of islands, with little or no contact between them. Cultural factors play an important role in the students' choice for a discipline and this is something that universities have to be aware of. Self-selection (or self-elimination) occurs, and for the faculties this can entail an imbalance, or even a cultural impoverishment. Taking academic fragmentation and the existence of faculty cultures for granted, or even ignoring or denying it, is not productive.

There is much to be gained in trying to expand the cultural richness of 
faculties. One way to do so, is to try to attract students from (hitherto) different cultural backgrounds. Another way to avoid cultural segregation could be an extension of the number of interdisciplinary studies. Gaff and Wilson have pointed out that interdisciplinary programs can be "immeasurably enriched by the very diversity of the faculty cultures" (Gaff \& Wilson, 1971, p. 201). By providing an opportunity for faculties to meet not only on a scientific, but also on a cultural level, interdisciplinary programs can build a bridge between faculty cultures and thus give the old notion of a universitas a modern shape.

This research also shows that the catholic identity of the university is somewhat lost. Only in the faculty culture of theology we can still find elements of this catholic identity. Most of the theology students are catholic, are interested in matters of religion, read about religious matters, speak about it and go to church. Students at the other faculties, and for that matter Dutch youngsters in general, are in a process of secularization. In Europe as a whole and in the Netherlands in particular, the decline in church membership is clearly apparent (Becker \& Vink, 1994), especially among the younger generation (Campiche, 1997). However, only few youngsters reject religion explicitly or prefer atheism (Janssen et al., 2000). This gives the catholic university an opportunity to redefine its catholic identity.

In order to renew the catholic identity of a university, O'Brien (2002) suggests the development of a small department of the university to study and reflect upon the basic university dogmas. This is exactly what the university of Nijmegen has done by creating two special institutions. In 1999 the Heyendaal Institute was founded, out of a need to redefine the mutual relevance of the Christian tradition and the contemporary culture. Interdisciplinary cooperation is an explicit element of research within this institute. And in 2001 the Soeterbeeck Program started, also with a dual goal of striving to give the catholic heritage a place within the identity of the university of Nijmegen and attempting to strengthen the intellectual contacts between the islands of the academic archipelago (Derkse, 2002).

\section{APPENDIX A}

List of independent variables used in the correspondence analysis. Numbered in order of importance, grouped by domains of world view. 


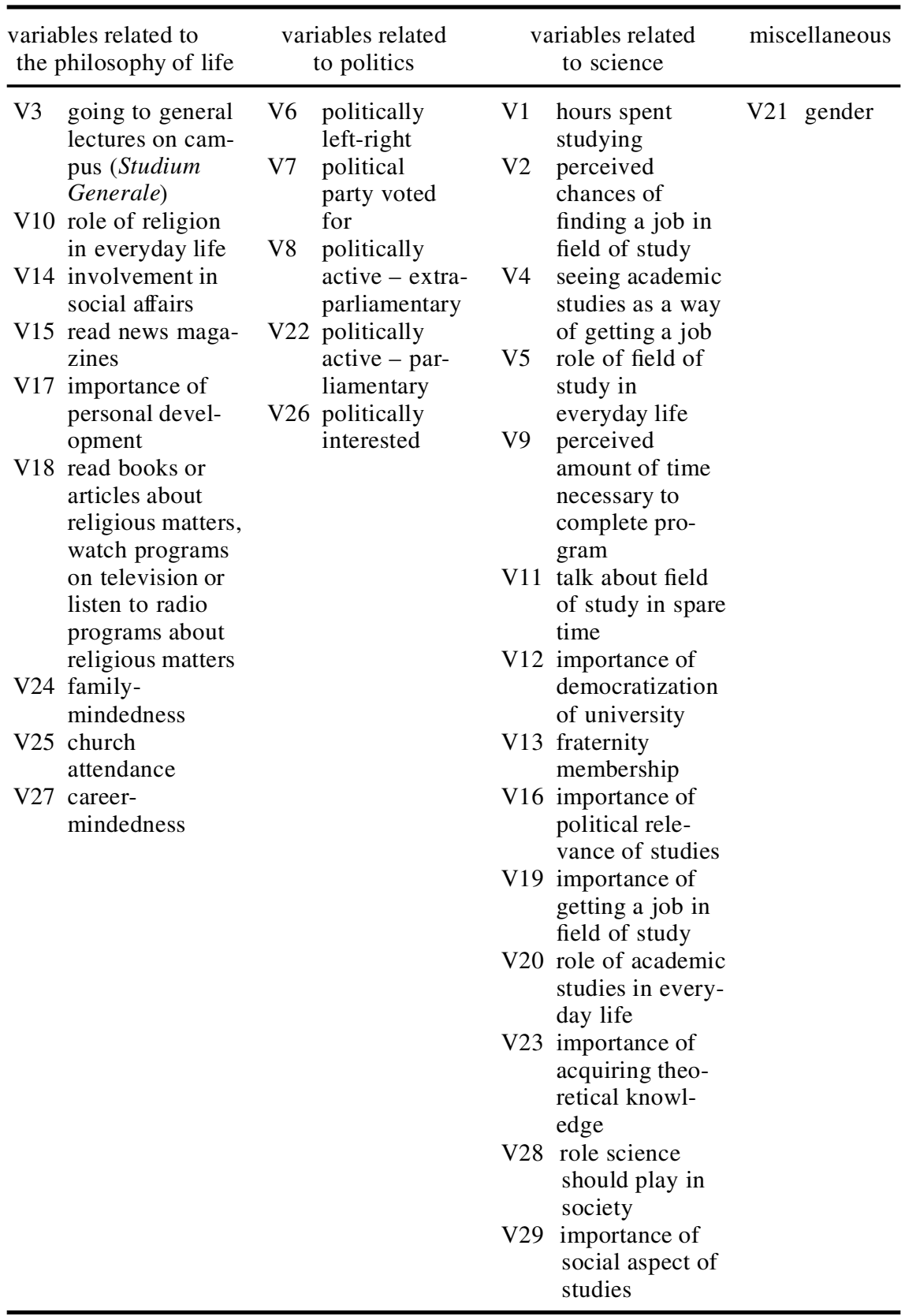




\section{NOTES}

1. “... die Verwirklichung der Einheit von Forschung und Lehre, Bildung und Erziehung in organischer Verbindung zur allseitigen humanistischen Bildung der Studenten".

2. "Das Kollegienhören ist nur Nebensache, das Wesentliche, dab man in enger Gemeinschaft mit Gleichgestimmten und Gleichaltrigen, und dem Bewußtseyn, daß es am gleichen Ort eine Zahl schon vollendet Gebildeter gebe, die sich nur der Erhöhung und Verbreitung der Wissenschaft widmen, eine Reihe von Jahren sich und der Wissenschaft lebe." (p. 114)

3. In 1900 there were 2,800 university students in the Netherlands, and in 1995 there were 185,200 . The strongest growth took place after the introduction of the system of study grants in 1954: from 1900 to 1955 university enrollment increased by an average of 500 students a year; from 1955 to 1995 the increase averaged nearly 4,000 a year (CBS 1979; CBS 1996).

4. Participation in academic education by students from lower social classes more than doubled in the 1936-1975 period (Koppen, 1991). It is difficult to find recent accurate data, since records no longer include social origin. The few data that are available cannot be compared because of different definitions of social class.

5. In 1900 only 7\% of university students were Roman Catholics, by 1955 the percentage had risen to $27 \%$ (Matthijssen, 1958). More recent data is hard to obtain.

6. In 1900 only $5 \%$ of the students in the Netherlands were female; the percentage grew steadily to $15 \%$ in 1950 , then more rapidly to $25 \%$ in 1975 , until it reached $46 \%$ in 1995 (CBS, div.).

7. D'66 stands for 'Democrats 1966'. The party was founded in 1966, as a reaction to the pillarization of the political system. It is a pragmatic liberal party and does not adhere to any ideology. D'66 is the most popular political party among all students: $38 \%$ say they would vote for it.

8. Health sciences in a broad sense is of course a very old field of study, but the discipline known today as health sciences is a recent one, and deals with more 'modern' issues like prevention, evaluation of the health care system, and the impact of environmental factors on health.

\section{REFERENCES}

Becher, T. (1989). Academic tribes and territories; intellectual enquiry and the culture of disciplines. Milton Keynes: Open University Press.

Becker, J., and Vink, R. (1994). Secularisatie in Nederland 1966-1991 [Secularization in the Netherlands 1966-1991]. Rijswijk: Sociaal en Cultureel Planbureau.

Biglan, A. (1973). Relationships between subject matter characteristics and the structure and output of university departments. Journal of Applied Psychology, 57 (3), pp. 204-213.

Bourdieu, P. (1988). Homo Academicus. Cambridge: Polity Press. Translated by Peter Collier.

Campiche, R., ed. (1997). Cultures des jeunes et religions en Europe [Youth culture and religion in Europe]. Paris: Les Éditions du Cerf.

CBS - Centraal Bureau voor de Statistiek (1979). 1899-1979 Tachtig jaren statistiek in tijdreeksen [1899-1979 Eighty years of statistics]. Den Haag: Staatsuitgeverij.

- (1996). Kwartaalschrift onderwijsstatistieken [Quarterly statistics of education]. Jaargang 3, nr. 1. Den Haag: Staatsuitgeverij.

Clark, B. R. (1987). The academic life. Small worlds, different worlds. Princeton: Carnegie Foundation.

Derkse, W. F. C. M. (2002). De universiteit als dienstbare gemeenschap [University as a subservient community]. Nijmegen: Katholieke Universiteit Nijmegen.

Gaff, J. G. \& Wilson, R. C. (1971). Faculty-cultures and Interdisciplinary Studies, Journal of Higher Education. vol. XLII (3), pp. 186-201. 
Hermans, C. (1994). Professionaliteit en identiteit [Professionalism and identity]. Den Haag: ABKO.

Hochbaum, J. (1976). Structure and process in higher education, pp. 5-15 in Kenneth A. Feldman, College and student, selected readings in the social psychology of higher education, New York: Pergamon Press.

Huber, L. (1990). Disciplinary Cultures and Social Reproduction, European Journal of Education. 25 (3), pp. 241-261.

Humboldt, W. von (1959). Bildung und Sprache. Eine Auswahl aus seinen Schriften [Education and language. A selection of his writings]. Besorgt von Clemens Menze. Paderborn: Verlag Ferdinand Schöningh.

Janssen, J., Prins, M., Baerveldt, C., \& Lans, J. van der. (2000). The structure and variety of prayer. Journal for Empirical Theology, 13 (2), 29-54.

Koppen, J. K. (1991). Een kwestie van discipline: over de externe democratisering van het wetenschappelijk onderwijs [A matter of discipline: the external democratization of academic education]. Amsterdam: Thesis Publishers.

Lammers, J., Peters, V. \& Weegen, T. van der (1989). Visuele analyse van een kruistabel. De techniek van correspondentie analyse [Visual analysis of a cross table. Technique for correspondence analysis]. Nijmegen: Instituut voor Toegepaste Sociale Wetenschappen.

Matthijssen, M. A. J. M. (1958). Katholiek middelbaar onderwijs en intellectuele emancipatie. Een sociografische facetstudie van het emancipatievraagstuk der Katholieken in Nederland [Catholic secondary education and intellectual emancipation. A sociographic study of the emancipation of Catholics in the Netherlands]. Assen: van Gorcum.

O'Brien, G. D. (2002). The idea of a Catholic university. Chicago: The University of Chicago Press.

Parsons, T. (1951). The social system. New York: The Free Press.

Pinner, F. A. (1963). Student trade-unionism in France, Belgium and Holland: Anticipatory socialization and role-seeking, Sociology of Education, 37, nr. 3, pp. 177-199.

Poelhekke, M. A. P. C. (1900). Het tekort der katholieken in de wetenschap [The shortage of Catholics in science]. (Nijmegen, Malmberg).

Prins, M., Janssen, J., \& Hutsebaut, D. (1997). Universitaire culturen in Vlaanderen en Nederland [Faculty cultures in Flanders and the Netherlands]. Tijdschrift voor Hoger Onderwijs, 15 (4), 296-318.

Snow, C. P. (1964). The Two Cultures: And a Second Look. An extended version of the two cultures and the scientific revolution. Cambridge: University Press. First printed 1959. Published as an article 'The Two Cultures' on October the 6th 1956 in the New Statesman.

Stoecker, J. L. (1993). The Biglan classification revisited, Research in Higher Education, 34 (4), pp. 451-464.

Verger, J. (1978). Universiteiten in de middeleeuwen [Universities in the middle ages]. Bussum: Unieboek.

Wolff, A. de (2000). Typisch Christelijk? Een onderzoek naar de identiteit van een christelijke school en haar vormgeving [Typically Christian? Research into the identity of a Christian school and its composition]. Kampen: Kok.

Address for correspondence:

Department of Psychology,

Catholic University Nijmegen,

The Netherlands.

P.O. Box 9104

6500 HE Nijmegen, The Netherlands.

e-mail: m.prins@psych.kun.nl 